\title{
Profilowanie kontekstu w paradygmatach językoznawstwa
}

\section{Aleksander Kiklewicz}

Uniwersytet Warmińsko-Mazurski w Olsztynie

\section{Wstęp}

Pojęcie kontekstu w językoznawstwie ma wiele aspektów (zob. Glück 1993: 331). W najogólniejszym rozumieniu kontekst to otoczenie jednostki, językowe lub pozajęzykowe (ekstralingwistyczne) środowisko jej funkcjonowania.

Rola kontekstu w komunikacji językowej jest odmienna w zależności od typu kultury: według Edwarda Halla (1959/1987), w kulturach o niskiej kontekstowości o przebiegu interakcji decydują elementy werbalne, właściwie komunikaty językowe, podczas gdy w kulturach o wysokiej kontekstowości pierwszeństwo ma środowisko komunikacyjne: towarzyszące znaki niewerbalne, atrybuty, scena komunikacji, osoby trzecie itd. Profilowanie (rodzaj eksploatowania) kontekstu zależy także od historycznie nacechowanych paradygmatów kultury. U podstaw niniejszego studium leży założenie o stopniowym nasileniu roli kontekstu w procesie zmiany paradygmatów językoznawstwa, a także teza o kontekstocentryzmie lingwistycznych badań nad językiem lat dziewięćdziesiątych XX wieku oraz pierwszej dekady XXI wieku.

\section{Paradygmaty językoznawstwa a synergiczny model znaku}

Istnieje kilka odmiennych stanowisk badawczych, dotyczących istoty paradygmatów językoznawstwa (nieraz traktowanych także jako paradygmaty filozofii języka - zob.: Stepanov 1985: 4; Rudenko 1993: 101; Kiklewicz, red. 2004). W koncepcji Ireneusza Bobrowskiego (1998: $34 \mathrm{i}$ n.) paradygmaty nauki (właśnie tak - nie paradygmaty językoznawstwa) są ufundowane na scjentycz- 
nych, alternatywnych wobec siebie zasadach dowodzenia twierdzeń. Bobrowski wyodrębnił w XX w. cztery rozumiane w ten sposób paradygmaty: indukcjonistyczny, weryfikacjonistyczny, falsyfikacjonistyczny oraz postmodernistyczny. Takie ujęcie wydaje się jednak nie do przyjęcia, gdyż zasady dowodzenia twierdzeń: dedukcja, indukcja, weryfikacja i in., w rzeczywistości są ambiwalentne wobec paradygmatów nauki, w pewnym stopniu ponadczasowe, uniwersalne, choć nie można też zaprzeczać temu, że poszczególnym kierunkom w nauce przysługują odrębne, regularnie kultywowane style kognitywne (zob. Kiklewicz 2009b).

Bardziej zasadne jest stanowisko badaczy, którzy przy określeniu paradygmatów opierają się na pojęciu ka te g or y z a cj i . Przy tym ujęciu każdy paradygmat odmiennie profiluje język, tzn. wyróżnia, eksponuje, wyświetla takie, a nie inne jego właściwości: synchroniczne lub diachroniczne, formalne lub funkcjonalne, idiograficzne (społecznie i kulturowo motywowane) lub nomotetyczne (wynikające ze specyficznej natury języka) itp. (zob. Kiklewicz 2007b: 61). Podobne stanowisko zajmuje rosyjski językoznawca i semiotyk Jurij S. Stepanov, który - opierając się na zaproponowanych przez Charlesa Morrisa aspektach znaku - wyodrębnił trzy paradygmaty lingwistyczno-filozoficzne:

- semantyczny (filozofia nazwy) skupia uwagę na relacjach znaków do pojęć i desygnatów;

- syntaktyczny (filozofia predykatu) czyni swoim przedmiotem relacje między znakami;

- pragmatyczny (filozofia wyrazów egocentrycznych) dotyczy relacji języka do sytuacji jego funkcjonowania, w szczególności do nastawień mentalnych użytkowników języka.

Propozycja Stepanova także budzi zastrzeżenia: jej wadą jest m.in. to, że uwzględniając trzy aspekty funkcjonowania znaków, rosyjski językoznawca zlekceważył ich for mę, a przecież forma (fonetyczna, gramatyczna, składniowa) całe stulecia (poczynając od gramatyki Paniniego) pozostawała głównym, a w niektórych okresach nawet jedynym obiektem opisu językoznawców. Dlatego w jednej z poprzednich publikacji (Kiklewicz 2007b: 26 i n.), przyjąłem założenie, iż koncepcja paradygmatów lingwistycznych powinna uwzględniać dwa podstawowe aspekty struktury znaku: treść i formę. Jako jeden z pierwszych podział ten w językoznawstwie zastosował Ferdynand de Saussure (2002: 90), który pisał, że znak językowy łączy pojęcie i obraz akustyczny: „Te dwa elementy [forma i treść - A. K.] są ściśle ze sobą złączone i wywołują się wzajemnie".

Na początku XX wieku ten bilateralny model znaku został rozbudowany. Wówczas językoznawcy - pod wpływem logiki matematycznej, a w szczególności teorii deskrypcji Bertranda Russella i teorii pragmatyzmu funkcjonalnego 
Williama Jamesa - zwrócili uwagę na poszczególne aspekty znaczenia: (1) odniesienie przedmiotowe (czyli znaczenie referencyjne/desygnacyjne) i (2) pojęciową interpretację desygnatów (czyli znaczenie sygnifikacyjne), choć Eugenio Coşeriu (2004: 103 i n.) pisał, że rozróżnienie tych dwóch kategorii znaczenia występuje już u Arystotelesa. Nowe ujęcie struktury znaku znalazło wyraz w trójkącie semantycznym Charlesa Kaya Ogdena oraz Ivora Armstronga Richardsa (1969: 11 i n.), zob. rysunek 1.

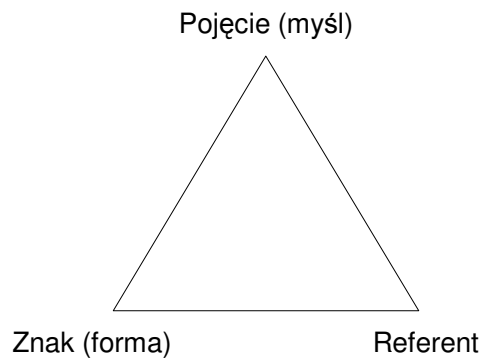

Rysunek 1. Trójkąt semantyczny Ogdena - Richardsa

Mimo że trójkąt semantyczny dawał większe możliwości interpretacji funkcjonalnych aspektów języka, to jednak nie rozwiązywał wszystkich problemów analizy semantycznej języka. W pierwszej połowie XX wieku przedstawiciele angielskiej szkoły funkcjonalnej zwrócili uwagę na brak uwzględnienia w tym modelu semantyki zewnętrznej, tzn. naturalnego powiązania znaków języka $\mathrm{z}$ ich otoczeniem komunikacyjno-kulturowym. Takie stanowisko zajął np. Bronisław Malinowski: z jego punktu widzenia trójkąt semantyczny Ogdena Richardsa nie odzwierciedla sytuacji mówienia, czyli właściwości kontekstowego funkcjonowania znaków (zob. Pisarkowa 2000: 153).

Proponowany w tej pracy synergiczny model znaku powstał na skutek swego rodzaju połączenia modelu Morrisa z modelem Ogdena - Richardsa: został zachowany podział na trzy aspekty znaku: semantykę, syntaktykę i pragmatykę, ale ponadto semantykę przedstawia się w sposób bardziej wyspecyfikowany - przy uwzględnieniu referencji i sygnifikacji. Pozwala to na przedstawienie znaku jako zespołu skonfigurowanych elementów:

- forma;

- znaczenie sygnifikacyjne (pojęciowe);

- znaczenie referencyjne (przedmiotowe);

- struktura (konstrukcja);

- kontekst (otoczenie).

To jednak nie wszystko. Nie do pominięcia jest także szósty element, który w serii poprzednich publikacji (Kiklewicz 1999: 127; 2004: 47; 2007b: 97) 
określiłem jako zas adę opty malności: wzajemna zależność, profilowanie poszczególnych aspektów znaku zależy od czegoś, co jest nie tylko poza znakiem, lecz w ogóle poza sytuacją komunikacyjną - chodzi o dominującą w określonej epoce konwencję kulturową, stanowiącą nadrzędny (chociaż niekoniecznie absolutny) czynnik działalności językowej. Każdemu areałowi, każdej sferze i każdej sytuacji komunikacyjnej zasada optymalności przyporządkowuje odpowiednie formy realizacji, a także stosowne modele ich konfiguracji. Na przykład w komunikacji potocznej zasada optymalności przeważnie realizuje się $\mathrm{w}$ postaci z a s a d y minimalnego działania: podmiot językowy dąży przede wszystkim do dostosowania formy i treści komunikatów do otoczenia aktu mowy, co powoduje niekompozycyjny charakter większości wyrażeń językowych, np. takie zjawisko, jak zdania niepełne (zob. Šeljakin 2002: 111 i n.). Mamy tu do czynienia z dekonstrukcją naturalną, u podstaw której leży synergiczna natura komunikacji potocznej.

Odwrotnie, w komunikacji oficjalnej (ogólnie rzecz biorąc - w komunikacji z obcym) obowiązuje schemat zachowania językowego, który w dużym stopniu oparty jest na konwencjonalnym kodzie językowym, a także na redundancji środków przekazu. Na przykład Aleksander A. Reformatskij (1987: 148) pisał, że organizacja tekstu graficznego, a mianowicie stosowanie redundantnych znaków graficznych, służy celowi ochrony sensu tekstu przed zniekształceniem $\mathrm{w}$ procesie jego przetwarzania przez czytelnika. Szczególnie redundantny charakter mają teksty komunikacji rytualnej oraz zrytualizowanej, por. zjawisko reduplikacji synonimów w tekstach religijnych (Kiklewicz 2005: 142). Tu można też twierdzić o hi perkonstrukcji tekstu .

Przy uwzględnieniu powyższych założeń aspekty znaku można przedstawić w następujący sposób (zob. rysunek 2). Zatuszowany fragment pentagramu wskazuje na trójkąt semantyczny Ogdena - Richardsa, który został inkorporowany do modelu synergicznego.

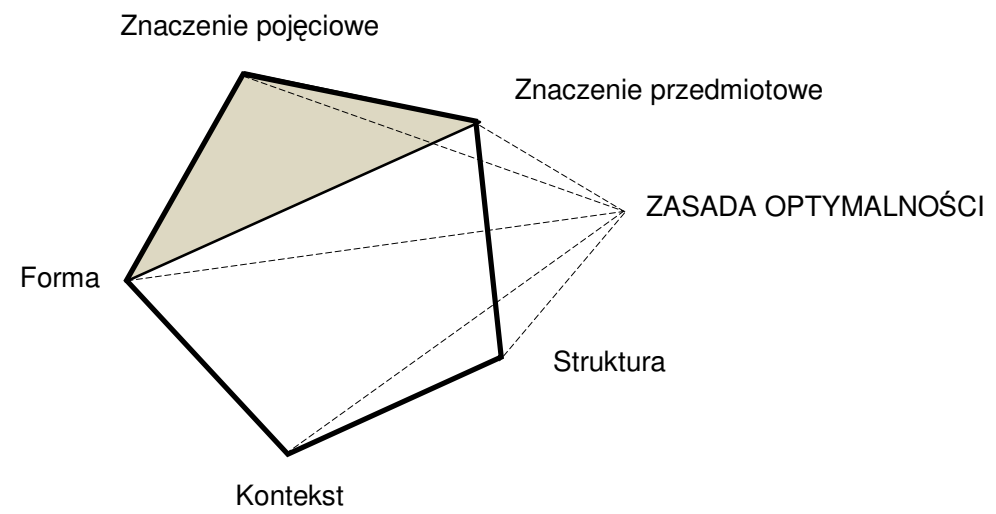

Rysunek 2. Model synergiczny znaku 
W zależności od typu kultury (panującej doby kulturowej) zasada optymalności określa stopień relewancji takich czynników działalności językowej, jak forma, znaczenie sygnifikacyjne, znaczenie referencyjne, struktura i kontekst. A więc $\mathrm{w}$ zależności od profilowania aspektów struktury znaku można wyodrębnić sześć paradygmatów nauki o języku:

- paradygmat formalistyczny (tradycyjny) - profilowanie formy jednostek językowych (od starożytności do drugiej połowy XIX wieku);

- paradygmat semazjologiczny (intensjonalny) - profilowanie zakodowanego w systemie języka systemu pojęciowego (druga połowa XIX wieku);

- paradygmat onomazjologiczny (ekstensjonalny, reistyczny) - profilowanie odniesienia przedmiotowego lub sytuacyjnego znaków (pierwsza połowa XX wieku, odrodzenie w latach siedemdziesiątych - osiemdziesiątych XX wieku);

- paradygmat strukturalny - profilowanie wirtualnych (paradygmatycznych) bądź liniowych (syntagmatycznych) relacji jednostek, jak również relacji między jednostkami różnego formatu w obrębie systemu języka (od pierwszej połowy do lat siedemdziesiątych XX wieku);

- paradygmat antropologiczny (poststrukturalistyczny) - profilowanie tzw. kontekstu pionowego, tzn. komunikacyjnego, kulturowego i kognitywnego środowiska funkcjonowania języka (od lat siedemdziesiątych XX wieku do początku XXI wieku);

- paradygmat uniwersalistyczny (inaczej: holistyczny) - profilowanie zasady optymalności.

Krótko omówię każdy z tych paradygmatów. Paradyg mat formali st y c z n y wywodzi się z tradycji szkoły Aleksandryjskiej i polega na skupieniu uwagi przede wszystkim na opisie gramatyki. W epoce średniowiecza była rozpowszechniona idea gramatyki uniwersalnej, którą w swoisty sposób przeniesiono do analizy porównawczo-historycznej, $\mathrm{z}$ tym że $\mathrm{w}$ tym drugim wypadku badacze dążyli do wyeksponowania ogólnych praw zmian historycznych, które w pierwszej kolejności dotyczyły fonetyki i morfologii.

Paradygmat semazjologiczny jest ufundowany na założeniach językoznawstwa psychologicznego XIX w., które przyniosło zalążki funkcjonalizmu: odrzucono tradycyjny prymat formy językowej na korzyść idiograficznego ujęcia języka, tzn. uwzględnienia powiązań między treścią znaków języka a obowiązującym systemem wartości kulturowych. Na przykład przedstawiciele niemieckiej szkoły Wilhelma Wundta rozumieli swoje zadanie badawcze jako odtworzenie mentalności narodowej poprzez badanie języka, folkloru i rytuałów. Choć, jak pisze Zygmunt Saloni (1999b: 521), „zagadnienia semantyczne $\mathrm{w}$ naturalny sposób występowały $\mathrm{w}$ pracach $\mathrm{z}$ zakresu filozofii, retoryki i gramatyki [a przede wszystkim logiki - A. K.] od początków istnienia tych 
dyscyplin”, to jednak przyznać należy, że semantyka lingwistyczna zarodziła się w obrębie dziewiętnastowiecznego psychologizmu.

Parad y g mat on o mazjol og i c zny jest, jak można sądzić, najmniej wyeksponowany w metodologii języka. Jest to podobno najmniej zauważany, 'cichy' (np. w porównaniu do głośnego strukturalizmu) paradygmat, który powstał w pierwszej połowie XX wieku. U podstaw tego kierunku językoznawstwa leży traktowanie znakowych jednostek języka jako nazw przedmiotów, osób, czynności, stanów itd. Profilowanie referencyjnego aspektu znaku należy zawdzięczać pracy Ludwiga Wittgensteina Tractatus logico-philosophicus (1921/1969), w której został zaproponowany ikoniczny model zdania, opierający się na idei symetrycznego odzwierciedlenia w strukturze znaku struktury desygnatu. Nie jest wykluczony także tu wpływ filozofii fenomenologizmu, najbardziej odczuwalny w pracach austriackiej szkoły Wörter und Sachen (Rudolf Meringer, Hugo Schuchardt i in.). Paradygmat ekstensjonalny obejmuje trzy kierunki badań lingwistycznych:

- badania w zakresie pól semantycznych, traktowanych (np. przez Franza Dornseiffa) jako grupy przedmiotowe, por. niem. Sachgruppen;

- opartą na logice matematycznej, w szczególności na semantyce logicznej Alfreda Tarskiego, składnię semantyczną; model ten w konsekwentny sposób zrealizowano w Gramatyce wspótczesnego języka polskiego (Topolińska 1984; zob. także: Karolak 2002);

- ufundowaną na teorii deskrypcji Russella lingwistyczną teorię referencji, szczególnie popularną w latach osiemdziesiątych XX wieku.

$\mathrm{Na}$ rozpowszechnienie się paradygmatu strukturalnego duży wpływ wywarła literatura modernizmu końca XIX wieku - początku XX wieku (pamiętajmy, że media masowe $\mathrm{w}$ tym okresie jeszcze nie opanowały w całości przestrzeni komunikacji publicznej, jak to stało się w latach osiemdziesiątych dziewięćdziesiątych $\mathrm{XX}$ w.). W tym czasie nastąpiła radykalna zmiana artystycznego stylu pisania: językową formę i strukturę tekstu interpretowano jako część przekazywanej informacji. To się odbiło echem w językoznawstwie: badacze skupili swoją uwage na strukturze jednostek językowych. Jeden z klasyków strukturalizmu Jurij M. Lotman (1973: 386) uważał, że pod wpływem malarstwa tekst poetycki stał się niejako wartością samą w sobie: poszczególne jednostki - wyrazy, straciły swoją autonomiczność, natomiast na pierwszy plan wysunęła się formalna struktura tekstu, idea tekstu jako konfiguracji znaków. Strukturalizm był reprezentowany przez kilka metodologicznie pokrewnych kierunków lingwistycznych, z których najważniejsze to: szkoła genewska, szkoła kopenhaska (tzw. glossematyka), szkoła praska, szkoła francuska (semiotyczna analiza dyskursu), szkoła tartusko-moskiewska, amerykańska lingwistyka generatywna. 
Paradygmat poststrukturalistyczny (traktowany także jako postmodernistyczny) (używam tych terminów zamiennie) polega na swoistej nobilitacji kontekstu, tzn. nasileniu różnego rodzaju elementów pozajęzykowych i pozatekstowych. Wpływ kontekstu powoduje dekonstrukcję tekstu, tzn. rezygnację z jego interpretacji linearnej, opartej na skonwencjonalizowanych syntagmatycznych relacjach składników leksykalnych - na rzecz interpretacji nielinearnej, synergicznej, opartej na współdziałaniu tekstu i kontekstu (zob. Spivey-Knowlton i in. 1993: 301 i n.).

Rozpowszechnienie w drugiej połowie XX wieku paradygmatu poststrukturalistycznego w dużym stopniu należy zawdzięczać zainteresowaniu się lingwistów komunikacją potoczną, której cechą jest - w określeniu Jacka Warchali (2003: 40) - s u b s t a n c jo n a ln ość, tzn. powiązanie tekstu ze środowiskiem interakcji werbalnej. Przede wszystkim w odniesieniu do komunikacji potocznej słuszne jest metaforyczne stwierdzenie Vladimira A. Zveginceva (1976: 178): „Sens pokona każdy opór języka - pod warunkiem, że jest przyporządkowany określonej sytuacji”.

Paradygmat uniwersalistyczny jest - jak można by oczekiwać - paradygmatem przyszłości. O ile dla wszystkich poprzednich paradygmatów językoznawstwa było charakterystyczne hipostazowanie, tzn. wyolbrzymienie jednego aspektu języka i lekceważenie innych aspektów, to nowy paradygmat nauki miałby połączyć wszystkie aspekty w jednym systemie konceptualnym. Nie możemy przecież zapominać, że żywotność języka, a także skuteczność naszych działań językowych jest uwarunkowana dynamicznym współdziałaniem wszystkich jego aspektów. Dlatego paradygmat uniwersalistyczny zakłada konieczność ujęcia interdyscyplinarnego języka, tworzenie jego modeli funkcjonalnych przy współpracy językoznawców, psychologów, socjologów, logików, cybernetyków i in. Przy tym nie wyklucza się możliwości, a nawet konieczności kontynuacji badań specjalistycznych w każdym odrębnym kierunku językoznawstwa.

\section{Lingwistyczne profilowanie kontekstu}

Lingwistyczna tradycja w Europie ukształtowała się na bazie badania jednostek języka: fonemów, morfemów, leksemów i zdań - rozpatrywanych jako różnego stopnia złożoności formy języka. Środowisko języka staje się obiektem systematycznych refleksji językoznawców dość późno, bo dopiero w XIX wieku, kiedy rozpowszechniła się (romantyczna w swej genezie) k o n c e p c ja milie u - wszechogarniającego środowiska (zob. Rewers 1996: 20 i n.). Do 
rozwoju badań lingwistycznych w tym kierunku przyczyniła się także dziewiętnastowieczna psychologia języka oraz wpływowe w pierwszej połowie XX wieku kierunki językoznawstwa otwartego: francuska i rosyjska szkoła socjologii języka, niemiecka szkoła antropologii języka (neohumboldtyzm) oraz angielska szkoła lingwistyki funkcjonalnej. W systemie wiedzy o języku powstała nowa opozycja: językoznawstwa wewnętrznego i zewnętrznego.

\subsection{Kontekst w strukturalistycznych badaniach nad językiem}

Dla początku XX wieku ogólnie był charakterystyczny relatywizm - przeniesienie uwagi z jednostek na ich funkcje, relacje, relewantne elementy otoczenia. Granicę między lingwistyką tradycyjną (w szczególności gramatyką szkolną) a lingwistyką strukturalną określa opozycja a tomizm - relatywizm. W końcu XIX wieku niemieccy młodogramatycy uważali atomizm za jedynie naukową zasadę opisu języka, pozwalającą na rozpatrywanie jednostek języka wyeliminowanych $\mathrm{z}$ ciagle płynnego otoczenia, dlatego młodogramatyczna historia języka stanowi w istocie rzeczy historię pojedynczych jednostek (zob. Christmann, Baum 1994: 397). Tradycja atomizmu ma swój początek w pracach Arystotelesa (zob. Świątek 1998: 35).

Na początku XX wieku powstała nowa koncepcja świata, w określeniu Stepanova (1985: 127) - „filozofia predykatu”, w której przedmiotem refleksji są fakty: sytuacje, zdarzenia, ufundowane na relacjach, czynnościach, stanach, procesach stany rzeczy. Powstało pojęcie zasady konstrukcyjnej (Tynjanov 2004: 9) jako dominującej konwencji, określającej skonfigurowanie elementów tekstu. Charakterystyczne dla tego nurtu badawczego założenie sformułował de Saussure. Według niego:

Cechy jednostki [oparte na jej relacjach do innych jednostek - A. K.] utożsamiają się z samą jednostką. W języku, jak w każdym innym systemie semiologicznym, to, co odróżnia dany znak, jest tym, co go stanowi. [...] Innymi słowy: język formą, a nie substancją (Saussure 2002: 145 i n.).

Warto podkreślić, że odrzucenie wymogu ekstensjonalności przy definicji klas na korzyść ujęcia deskryptywnego (,warunek przynależności wyznacza klasę") - jak uważał Willard Van Orman Quine (1995: 39 i n.) - stanowiło ogólną tendencję rozwoju myśli logiczno-filozoficznej w końcu XIX wieku oraz w XX wieku. Od atomizmu językoznawstwa komparatystycznego odstąpiono na korzyść ujęcia systemowego, które w sposób nieunikniony zakłada 
istnienie właściwości obiektów, wynikających $\mathrm{z}$ ich relacji $\mathrm{z}$ otoczeniem, w szczególności uwarunkowanych wymogiem adaptacji (jak np. w teorii intelektu Jeana Piageta, zob. Kiklewicz 2007b: 63 i n.).

Relatywizm, o którym tu mowa, stanowi pewną odmianę funkcjonalizmu. Już w obrębie dziewiętnastowiecznego psychologizmu zaczyna się epoka językoznawstwa funkcjonalnego. Jego przedmiotem są relacje jednostek językowych mniejszego formatu do jednostek większego formatu (fonemów do morfemów, morfemów - do leksemów, leksemów - do zdań, zdań - do tekstów) lub do jednostek pozajęzykowych (por. relacje wyrazów do konceptów lub referentów, relacje zdań do logicznych form myśli lub stanów rzeczy). Doktryna funkcjonalna $\mathrm{w}$ językoznawstwie bazuje na traktowaniu języka jako ukierunkowanego systemu, ujęciu jednostek językowych $w$ aspekcie ich przeznaczenia. Funkcjonalizm, jak podkreśla Oleg Leszczak (2000: 247), polega na idei relatywizmu egzystencji obiektów, na ich zasadniczej zależności od innych obiektów.

Choć strukturalizm w europejskim i amerykańskim językoznawstwie pierwszej połowy, a także lat pięćdziesiątych-sześćdzisiątych XX wieku kojarzy się przede wszystkim z ujęciem immanentnym języka, to jednak kategoria kontekstu nie była obca badaczom tej generacji. Przyjęta przez strukturalistów orientacja na opis relacji jednostek oznaczała - w swej konsekwencji uwzględnienie elementów otoczenia, traktowanego jako kontekst językow y. Zastosowanie kategorii kontekstu w lingwistyce strukturalnej dotyczy wszystkich poziomów systemu języka: fonologii, morfologii, semantyki leksykalnej i składni.

\subsubsection{Kontekst językowy w zakresie fonetyki}

$\mathrm{Na}$ poziomie fonetycznego podsystemu języka otoczenie syntagmatyczne odgrywa zasadniczą rolę przy opisie procesów fonetycznych: asymilacji, dysymilacji, akomodacji i in. (zob. Saloni 1999a: 313), oraz przy opisie zjawisk morfonologicznych - funkcjonowania jednostek fonetycznych w strukturze morfemów, tzn. jako narzędzi realizacji znaczeń kategorii gramatycznych (Pociechina 2010: 36).

Za decydujące kryterium określenia statusu fonologicznego dźwięków uznano dystrybucję jako zespół jednostek fonetycznych, należących do otoczenia danej jednostki. Dystrybucja w językoznawstwie jest rozumiana jako rodzaj konfiguracji jednostek, innymi słowy - jako ograniczenia „,co do kontekstów, w jakich [jednostka językowa - A. K.] może występować" (Lyons 1975: 84). W zależności od dystrybucji, czyli otoczenia dźwięku, rosyjski językoznawca Nikołaj S. Trubiecki (1970: 45 i n.), choć nie używał terminu 
'dystrybucja', wyodrębnił fonemy oraz ich obligatoryjne i fakultatywne warianty Na przykład w wypadku równoważności dystrybucyjnej pozycje jednostek są jednakowe, lecz ich funkcje sygnifikacyjne (tzw. dystynktywne) są odmienne: jednostki fonetyczne samodzielnie rozróżniają dwa wyrazy (lub też dwa morfemy). Taki typ dystrybucji wskazuje na przynależność jednostek do różnych fonemów, ogólnie rzecz biorąc - do różnych inwariantów językowych, por.:

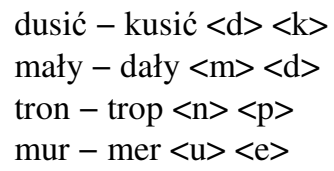

Dystrybucja komplementarna zachodzi wówczas, gdy jednostki nie występują $\mathrm{w}$ jednakowej pozycji, lecz pełnią tę samą funkcję sygnifikacyjną stanowią element planu wyrażenia tego samego wyrazu lub morfemu. Jednostki takie uważane są za alofony - warianty fonemów, występujące w mowie realizacje zakodowanych w systemie języka inwariantów:

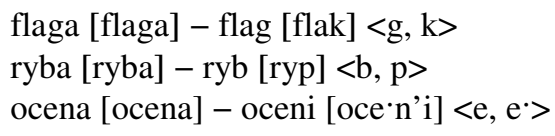

\subsubsection{Kontekst językowy w zakresie morfologii}

W morfologii zasada dystrybucjonizmu (szczególnie rozpowszechniona np. w językoznawstwie niemieckim, zob.: Helbig, Buscha 1983; Hermann 1992: 154; Drosdowski 1984 i in.) znalazła wyraz przede wszystkim w klasyfikacjach gramatycznych (paradygmatycznych), opartych na cechach syntaktycznych (walencyjnych) wyrazów. Takie podejście, jak podkreśla Kurt Braunmüller (1985: 301), jest szczególnie ważne w odniesieniu do tzw. wyrazów funkcyjnych, tzn. synsemantycznych, pełniących $\mathrm{w}$ zdaniu rolę uzupełnień konstrukcji wyrazów autosemantycznych (takich jak: rzeczownik, czasownik, przymiotnik, przysłówek). Brak znaczenia pojęciowego wyrazów funkcyjnych powoduje, że właściwości kombinatoryczne stają się jedyną podstawą ich klasyfikacji. Przy zastosowaniu zasady dystrybucyjnej Harald Weydt, Klaas-Hinrich Ehlers (1987: 7 i n.) dokonali klasyfikacji niemieckich partykuł, a Maciej Grochowski (1997: 9 i n.) - wyrazów nieodmiennych w języku polskim.

Odrębną wersję tej metody lingwistycznej stanowi analiza dystrybucyjno-stat ystyczna (zob. Kempgen 1981). Jej klasyczne zastosowanie zademonstrował rosyjski językoznawca Anatolij J. Šajkevič (1980). Według 
niego, klasyfikacja naturalna $\mathrm{w}$ lingwistyce powinna opierać się na cechach funkcjonalnych jednostek, a mianowicie dotyczących ich łączliwości z innymi jednostkami w potoku mowy. W założeniu Šajkeviča, jednostki, należące do wspólnych klas paradygmatycznych, posiadają także wspólne właściwości kombinatoryczne. Dlatego w celu gramatycznej klasyfikacji jednostek zostały przeanalizowane ich (prawe i lewe) kolokacje, uwzględniono też częstotliwość ich występowania w tekstach. W ten sposób Šajkevič wyodrębnił jedenaście części mowy w języku angielskim, traktując część mowy jako klasę jednostek leksykalnych o maksymalnie wysokim wskaźniku korelacji ze względu na cechy dystrybucyjne.

Zwolennicy reistycznego definiowania kategorii językowych, tzn. opartego na pojęciu referencji, zrezygnowali w latach osiemdziesiątych - dziewięćdziesiątych XX wieku z zasady dystrybucjonizmu - decyzje o przynależności jednostek do klas semantycznych podejmowano przeważnie na podstawie intuicji. Tak więc wielu badaczy uznało, że do kategorii referencyjnych aktualizatorów (tzw. determinatorów) grup imiennych należą nie tylko rodzajniki czy zaimki wskazujące, lecz także wyrazy kwantyfikujące: 'wszyscy', 'każdy', 'zawsze', 'wszędzie', 'żaden' itp., a nawet liczebniki. Takie (w istocie rzeczy błędne) stanowisko zajęła np. Renata Grzegorczykowa (1992: 273), która zaproponowała, aby w ogóle zrezygnować z pojęcia kwantyfikacja, zastępując je pojęciem referencji. Zastosowanie zasady dystrybucyjnej wykazuje niesłuszność takiego ich traktowania (zob. Kiklewicz 1998: 65 i n.). Na to, że wykładniki kwantyfikacji, wykładniki referencji i wykładniki określoności/nieokreśloności należą do odmiennych klas paradygmatycznych, wskazuje ich równoważność dystrybucyjna:

ws zystkie jej sprawy - *wszystkie jakieś sprawy; *jej nasze sprawy ws zystkie poprzednie zdarzenia - *poprzednie następne zdarzenia b yłe m t a m wszędzie - *byłem tam tu; *byłem wszędzie gdziekolwiek k a żd y taki gest - *każdy żaden gest; *taki owaki gest

W podobny sposób Zvegincev przekonywał o niestosowności kryterium przedmiotowo-pojęciowego przy określeniu synonimii leksykalnej. W jego ujęciu, synonimy to ,minimalne modele dystrybucyjne, pozwalające wyeksponować tożsamość w zakresie łączliwości wyrazów" (Zvegincev 1968: 137 i n.).

\subsubsection{Kontekst językowy w zakresie składni}

Zastosowanie kategorii kontekstu językowego w zakresie składni zaowocowało uporządkowaniem relacji syntagmatycznych w zdaniu oraz w grupie wyrazowej. Za przykład może posłużyć zaproponowana przez Cezarego Piernikarskiego 
dystrybucyjna klasyfikacja wyrazów, oparta na pojęciu konotacji jako wymagania składniowego, dotyczącego współwystępowania składników wyrazowych (tzw. syntaktemów) w jednej sekwencji syntagmatycznej (w polskiej tradycji lingwistycznej używa się także terminu 'walencja', zob. Karolak 2002: 39). W zależności od właściwości konotacyjnych Piernikarski (1990: 81 i n.) podzielił wszystkie wyrazy synsemantyczne na cztery klasy: S, AdS, V, AdV, które tylko częściowo pokrywają się z tradycyjnymi rzeczownikami, przymiotnikami, czasownikami i przysłówkami.

\subsubsection{Kontekst językowy w zakresie semantyki leksykalnej}

W obrębie syntaktycznych cech kontekstowych wyróżniono także zjawisko selekcji jako dystrybucji właściwości semantycznych partnerów syntagmatycznych w zdaniu lub w grupie wyrazowej (ideę cech selekcyjnych w pewnym stopniu zastosowano pod wpływem popularnego w latach siedemdziesiątych-osiemdziesiątych XX wieku strukturalizmu syntagmatycznego Radivoja F. Mikusa 1972). Językoznawcy szczegółowo opisali typy łączliwości semantycznej leksemów w obrębie grup syntagmatycznych, zwłaszcza wymogi selekcyjne czasowników (zob. Ważnik 2008: 98 i n.). Zjawisko polisemii (metafory i metonimii) strukturaliści także traktowali, opierając się na pojęciu dystrybucji, a mianowicie jako zakłócenie wymogów selekcyjnych wyrazów (zob. Żmigrodzki 1995: 55 i n.).

W obrębie moskiewskiej szkoły semantycznej powstała koncepcja sfery oddziaływania jednostek leksykalnych (Boguslavskij 1996), której istota polega na tym, że określonemu wyrazowi przyporządkowuje się zespół towarzyszących mu w otoczeniu syntagmatycznym i konotowanych przez jego znaczenie leksykalne form wyrazowych. W ten sposób analiza kontekstu syntagmatycznego umożliwiła opis struktury znaczenia leksykalnego wyrazów. Ujęcie to okazało się szczególnie przydatne do opisu wyrazów funkcyjnych, których treść semantyczna w dużym stopniu polega na regułach selekcyjnych, innymi słowy - na możliwych vs. niemożliwych, regularnych vs. nieregularnych, stylistycznie nacechowanych vs. nienacechowanych kontekstach językowych.

Jeden z założycieli moskiewskiej szkoły semantycznej Jurij D. Apresjan (1974: $60 \mathrm{i}$ n.) pisał o decydującej roli cech dystrybucyjnych (a mianowicie dotyczących łączliwości morfologiczno-składniowej, leksykalnej bądź semantycznej wyrazów) przy opisie klas semantycznych w systemie leksykalnym języka. Przyjęto założenie, że podobieństwo semantyczne wyrazów znajduje odzwierciedlenie w ich łączliwości syntagmatycznej, a więc na podstawie danych o łączliwości można postulować przynależność jednostek do tej samej klasy semantycznej, choć Apresjan (1974: 219) zdawał sobie sprawę z ograniczeń tej zasady. 


\subsection{Kontekst w poststrukturalizmie}

Paradygmat poststrukturalistyczny odrzucił respektowany przez zwolenników de Saussure'a prymat języka; w dużym stopniu pod wpływem badań nad tekstem w drugiej połowie XX wieku lingwiści stwierdzili, że struktura znaku nie wyjaśnia wszystkich jego właściwości funkcjonalnych, a strukturalizm to tylko określona opcja badawcza. Miejsce ,,języka samego w sobie” zajmuje język jako narzędzie działalności - komunikacyjnej lub poznawczej. Nawiązując do Wilhelma von Humboldta - prekursora tego kierunku nauki o języku, współczesny teoretyk lingwistyki komunikacyjnej Roy Harris (1981: 4) wprost określa język jako rodzaj działalności. Przy uwzględnieniu kontekstu działalności obiekt językoznawstwa jest traktowany (i opisywany) jako zjawisko o charakterze antropologicznym (synergicznym, ekologicznym).

Założenie poststrukturalistów polega na uwzględnieniu szeroko rozumianego otoczenia znaków, a mianowicie otoczenia komunikacyjnego - interakcji językowej, lub otoczenia kognitywnego - sfery mentalnej kategoryzacji danych doświadczalnych. Podstawy tego nurtu badawczego zostały założone w pierwszej połowie XX wieku przez szkołę Michała M. Bachtina. Według niego, każda wypowiedź jest ulokowana w określonej sferze komunikacji, dlatego „nie sposób określić własne stanowisko bez odniesienia go do innych stanowisk" (Bachtin 1979: 271). Podobnego zdania był Valentin N. Vološinov, najbardziej znany badacz z kręgu Bachtina. W ujęciu Vološinova (1995: 283 i n.), każda wypowiedź jest zorientowana w kontekście ideologicznym, na który składają się stereotypy kultury, nastawienia sądzeniowe użytkowników języka itp.

W ostatnich dziesięcioleciach XX wieku w Europie Zachodniej szeroki rozgłos - przede wszystkim w środowisku historyków - zyskała s z k oł a c a mbridge'owska (por. prace takich badaczy jak: Pocock 1972; Phillipson, Skinner 1993). Głównym jej założeniem jest kontekstualizm, tzn. dążenie do zinterpretowania wszelkich tekstów kultury na podstawie kontekstów ideowych, uwarunkowanych sytuacjami historycznymi (zob. też: Bevir 1999). Zamknięte $\mathrm{w}$ określonej przestrzeni historycznej oraz spójne pod względem merytorycznym konteksty ideowe składają się na pojęcie paradygmatu. Kategoria kontekstu jest zatem traktowana jako niezbędny element każdej analizy nie tylko tekstów językowych, lecz także historii idei.

Poststrukturalizm w językoznawstwie można też określić jako paradygmat kontynuacyjny, ponieważ jego założenie programowe polega na tym, że język wchodzi do wspólnego kontinuum kultury, a komunikacja językowa stanowi swego rodzaju współdziałanie sił, czyli fenomen zasadniczo synergiczny. 
W językoznawstwie rozróżnia się kontekst wąski (mikrokontekst) oraz kontekst szeroki (makrokontekst) (zob. Barchudarov 1975). W pierwszym wypadku chodzi o najbliższe otoczenie jednostki językowej - jej kolokacje, natomiast w drugim - szersze otoczenie, na które składają się jednostki, z którymi dana jednostka nie jest połączona związkiem gramatycznym lub związkiem przyległości. Rozważmy tłumaczenie na język polski fragmentu powieści Jerome’a D. Salingera Buszujacy w zbożu (zob. też: Barchudarov 1975):

Then I got this book I was reading and sat down in my $\mathrm{ch}$ a i r.

Angielskiemu rzeczownikowi chair w języku polskim odpowiada zarówno 'krzesło', jak i 'fotel'. Tłumacz zatem może zastanawiać się nad wyborem odpowiednika. Sprawę wyjaśnia szerszy kontekst powieści, a mianowicie jedno $\mathrm{z}$ kolejnych zdań, w którym występuje wyrażenie the arms 'poręcza' - nie pozostaje więc wątpliwości, że autorowi oryginału chodziło właśnie o fotel:

The arms were in sad shape, because everybody was always sitting on them, but they were pretty comfortable chairs.

Pojęcie szerokiego kontekstu obejmuje także bardzo popularne ostatnio (szczególnie w takich dyscyplinach, jak hermeneutyka lingwistyczna, lingwistyka tekstu i in.) zjawisko in tertekstualności. Istota tej kategorii polega na współdziałaniu tekstu ze środowiskiem kulturowym - tzw. kontekstem pionowym, warunkującym występowanie $\mathrm{w}$ formalnej i semantycznej strukturze tekstu elementów zapożyczonych z innych źródeł tekstowych, na co wskazuje Stanisław Gajda. Według niego

[...] punktem wyjścia dla teorii intertekstualności jest teza, że każdy tekst jest tworzony i odbierany nie tylko $\mathrm{w}$ odniesieniu do kodowych potencji języka, lecz pozostaje także w odniesieniu do tekstów uprzednich i następujących oraz zawiera ślady (sygnały) tych odniesień (Gajda 2010: 13).

Teoria intertekstualności powstała na gruncie postmodernistycznego stylu pisania, innymi słowy - przyjęcia koncepcji tekstu ,jako splotu różnorodnych (w tym sprzecznych) porządków wypowiedzi” (Nycz 1993: 45; zob. też: Vizel' 1999: 173 i n.). Charakterystycznym zjawiskiem postmodernizmu jest hybrydyczność tekstów, inaczej - synkretyzm stylistyczny, np. nierozróżnienie stylu wysokiego i niskiego (zob. Birken-Silverman 2005; Hinnenkamp, Meng 2005: 9 i n.; Lewicki 1996: 113; McLuhan 2001: 398; Ożóg 2001: 58; Zmarzer 1994: 222). Rozpowszechniło się też wprowadzone w 1965 roku przez amerykańskie- 
go matematyka i filozofa Teda H. Nelsona pojęcie hipertekstu - zespołu mniej lub bardziej zamkniętych, niezależnych fragmentów tekstowych (tzw. węzłów tematycznych czy też leksji), połączonych w przestrzeni multimedialnej z tekstem bazowym (tzw. scenariuszem). Rodzaj uzupełnianej w ten sposób informacji jest rozmaity: są to aluzje, zestawienia, interpretacje, egzemplifikacje itp. (Kiklewicz 2010b: 240). Czytanie powstającego w taki sposób intertekstu traci charakter liniowego przetwarzania rzędów syntagmatycznych, tzn. gramatycznie uporządkowanej informacji językowej - czytanie staje się procesem wirtualnym, zakładającym aktywny udział adresata, a mianowicie - „swobodna nawigację" użytkowników między leksjami (zob. Prokopczuk, Tiutenko: 2004, 233). Już w latach sześćdziesiątych $X X$ w. badacze w zakresie tekstologii i hermeneutyki literatury artystycznej aktywnie używali pojęcia „podtekst” (zob. Taranovskij 1967).

Istnieje także trzeci typ otoczenia jednostek języka - k o n te ks t e k s tralingwistyczny. Chodzi o szeroko rozumiane środowisko komunikacji językowej, łączące w sobie takie elementy, jak: podmioty interakcji, miejsce (scena) i czas interakcji, narzędzia interakcji, relacja statusów społecznych jej uczestników, kanały i zastosowane kody przekazu informacyjnego, mentalne i emocjonalne nastawienia podmiotów, oczekiwane następstwa interakcji i in. Właśnie taki typ kontekstu stał się głównym obiektem refleksji lingwistycznych w obrębie paradygmatu poststrukturalistycznego. Za centralną kategorię funkcjonowania języka - przede wszystkim za sprawą badań Johana Gumpeza i Della Hymesa - uznano kontekstualizację, czyli powiązanie między faktami języka a środowiskiem antropologicznym, w szczególności komunikacyjnym. W myśl współczesnej socjologii i antropologii języka zadanie podmiotu językowego polega nie na produkowaniu gramatycznie poprawnych wyrażeń (jak to traktowała lingwistyka generatywna), lecz na tym, aby poprzez zastosowanie i dostosowanie do warunków sytuacji aktu mowy osiągnąć zamierzony cel komunikacyjny. Jedynie w odniesieniu do kontekstu sytuacji komunikacyjnej wyrażenia języka otrzymują stosowną interpretację.

Współczesne zainteresowanie językoznawców (a także filozofów, psychologów społecznych, antropologów) środowiskiem komunikacji językowej, czyli kontekstocentryzm, powstało na skutek odrodzenia w drugiej połowie $\mathrm{XX}$ wieku sensualizmu, a także rozpowszechnienia ujęcia fenomenologicznego języka. W dużym stopniu nowy porządek w językoznawstwie został uwarunkowany także postmodernistycznym stylem pisania, w którym kontekstowe odniesienia elementów tekstu dominują nad ich treścią skonwencjonalizowaną (systemowa) oraz sposobem ich strukturalizacji liniowej. W terminologii Tadeusza Skalskiego (2002) oznacza to pierwszeństwo funkcji medialnej języka przed funkcją semantyczną. Za przykład takiej eksploatacji kontekstu ekstralin- 
gwistycznego mogą posłużyć współczesne dyskursy komunikacji masowej, w których - według znanego określenia Marshalla McLuhana (2004: 40 i n.) - ,środek przekazu jest przekazem".

Środowisko komunikacyjne nie jest jednorodne - występuje w nim wiele czynników: społecznych, historycznych, poznawczych, egzystencjalnych, geofizycznych i in. Dlatego można wyodrębnić kilka typów kontekstów ekstralingwistycznych:

- kontekst kulturowy, w szczególności ideologiczny - zespół „doświadczeń pozajęzykowych" (Nęcki 2000: 97), tzn. wiedza o świecie, a także przekonania, wierzenia, założenia itp.;

- kontekst sytuacyjny (proceduralny) - układ sytuacji komunikacyjnej, konfiguracja takich jej elementów, jak: uczestnicy, obserwatorzy, scena, atrybuty $\mathrm{i}$ in.;

- kontekst społeczny - relacje interpersonalne w aktach mowy, takie jak równość - nierówność, współpraca - przyjaźń, dominowanie - uleganie i in.;

- kontekst dyspozycyjno-intencjonalny (w szczególności zadaniowy) - stany i zamierzenia partnerów komunikacyjnych, zaprogramowane efekty zainicjowanych działań komunikacyjnych.

\subsubsection{Kontekst kulturowy}

Na kontekst kulturowy składają się wszystkie elementy doświadczeń mentalnych i emocjonalnych użytkowników języka, które towarzyszą przetwarzaniu informacji językowej. Zakłada się, że zewnętrzne reakcje oraz wewnętrzne przeżycia człowieka są kategoryzowane $\mathrm{w}$ formie pojęciowej lub obrazowej. W różnych ujęciach badawczych kulturowa kategoryzacja świata przybiera rozmaite postacie: konceptów, stereotypów, standardów semantycznych, ram odniesienia, schematów interpretacyjnych, frejmów, tezaurusów, wyidealizowanych modeli kognitywnych itd. Jednakże niezależnie od stosowanej terminologii badaczy łączy przekonanie, że po pierwsze, istnieją względnie skonwencjonalizowane, psychiczne formy uogólnienia „,rozproszonych urywków doświadczenia lub informacji” (McQuail 2008: 374); po drugie, zarówno proces kodowania, jak i proces dekodowania komunikatów językowych realizuje się przy uwzględnieniu szerszego tła kognitywnej kompetencji człowieka; po trzecie, formami językowej realizacji standardów semantycznych są presupozycje (Awdiejew 1999: 47; Przybyszewski 2010). Zastosowanie kompetencji kulturowej w celu interpretacji wyrażeń językowych nazywa się inferencją. Rozważmy np. dwie wypowiedzi pytające:

Gdzie jest mój szlafrok?

Gdzie jest twój szlafrok? 
Można by sądzić, że powyższe wyrażenia różnią się tylko dwoma elementami: zaimkami 'mój' i 'twój'. Jednakże rzeczywista różnica jest głębsza, ponieważ odbiorca aktu aktualizuje swoją wiedzę o typach sytuacji komunikacyjnych, w których każda replika stanowi naturalny element scenariusza zdarzeń. Przy uwzględnieniu inferencji pierwszą wypowiedź zinterpretujemy raczej jako prośbę o pomoc ('Proszę mi pomóc znaleźć mój szlafrok'), możliwe też - jako zarzut ('Gdzieś zapodziałeś mój szlafrok'), podczas gdy drugą wypowiedź odbieramy raczej jako pytanie albo jako polecenie ('Nie włożyłeś szlafroka - musisz włożyć szlafrok'). Oczywiście, w zależności od tła doświadczalnego partnerów komunikacyjnych interpretacja dowolnej wypowiedzi może przybierać rozmaite, nawet okazjonalne formy.

W teorii proceduralnej Waltera Kintscha i Teuna A. van Dijka (1978) inferencję uwzględnia się na poziomie rozumienia tekstu. Apelacja do zachowywanych w pamięci długotrwałej elementów wiedzy encyklopedycznej staje się niezbędna w przypadku niezleksykalizowania wykładników koherencji poszczególnych bloków informacyjnych, np. pojedynczych fraz. Dzięki inferencji generowane są nowe propozycje, które wypełniają luki w semantycznej strukturze tekstu, zamykając w ten sposób pewne bloki informacyjne.

Rola kontekstu kulturowego szczególnie wzrasta w przypadku wyrażeń niekompozycyjnych, tzn. strukturalnie niepełnych: baza apercepcyjna użytkowników języka staje się wręcz niezbędna w celu uzupełnienia brakującej informacji (zob. Kiklewicz 2006: 13 i n.). Na przykład wiele grup wyrazowych, zawierających przymiotnik względny, jak pisze Dorota Szumska (1999: 10 i n.), powstaje w rezultacie kompresji strukturalnej (przykłady prasowe z pracy Szumskiej):

lniany szyk < szyk ubrań uszytych z lnu

lniane lato < lato, podczas którego nosi się przede wszystkim ubrania uszyte z lnu

W większości przypadków zarówno generowanie konstrukcji skompresowanych, jak i ich rozumienie wymaga od podmiotów językowych zaktualizowania fragmentu wiedzy o świecie, inną kwestią jest to, że wiedza ta może być w różnym stopniu skonwencjonalizowana (zob. Szumska 1999: 16).

Ponieważ wyrażenia metaforyczne w swej istocie także powstają na skutek kompresji strukturalnej (Karolak 1999: 364), ich rozumienie w dużym stopniu wymaga zastosowania elementów bazy apercepcyjnej. Teoria metafory, np. w klasycznym dziś ujęciu Michaela Blacka, staje się zatem szczególnym przypadkiem hermeneutyki. Przykładowo, rozpowszechniona w wielu językach europejskich metafora wilka (czyli metaforyczne określenie osoby złej, wrogiej, niebezpiecznej, wzbudzającej nieufność, por. 'Wilkiem komuś z oczu patrzy') pochodzi z tekstu baśni Czerwony Kapturek (Zill 2010: 181). Rola podobnych 
apelacji kulturowych jest szczególnie znacząca w przypadku metafor nieskonwencjonalizowanych.

Kontekst kulturowy w dużym stopniu przyczynia się także do powstania k o n o ta c ji, które towarzyszą tzw. znaczeniom systemowym (słownikowym). Konotacje w istotny sposób uzupełniają realnie funkcjonującą semantykę znaków językowych, tworząc wraz ze znaczeniem systemowym kategorię, którą określa się jako koncept. W odróżnieniu od znaczenia systemowego koncept zawiera wiele „sensów naddanych” (termin Aleksego Awdiejewa), tzn. uwarunkowanych obszarami kultywowania określonych znaczeń.

Zagadnieniem tym zajmuje się współczesna etnolingwistyka, a także poniekąd lingwistyka interkulturowa. Badacze opisują np. odmienne konotacje tych samych znaków w różnych kulturach. Przykładowo, w kulturze rosyjskiej скворец 'szpak' wywołuje jednoznacznie pozytywne asocjacje, o czym świadczy m.in. forma derywatu o nacechowaniu pieszczotliwym: скворушка 'szpaczek'. W amerykańskim kręgu kulturowym starling 'szpak' nie posiada pozytywnych skojarzeń, gdyż ten ptak jest uważany przez Amerykanów za szkodnika. Podobnie różnią się pol. 'pożar' i ang. fire. W większości użyć znaczenia i konotacje (negatywne) tych wyrazów są jednakowe, lecz po angielsku można powiedzieć: like house of fire, co dosłownie znaczy 'jak dom w płomieniach', ale metaforycznie bywa używane z pozytywną konotacją: 'szybko, niezwłocznie' lub 'z powodzeniem', co nie jest charakterystyczne np. dla języka polskiego.

Międzykulturowy aspekt konotacji realizuje się także na poziomie poszczególnych dyskursów. Tak więc $\mathrm{w}$ dyskursie publicystycznym są rozpowszechnione tzw. słowa sztandarowe (zob. Pisarek 2000: 19; 2002), którym towarzyszy skonwencjonalizowane nacechowanie aksjologiczne - pozytywne (w przypadku tzw. miranda) bądź negatywne (w przypadku tzw. kondemnanda). Na przykład z badań ankietowych, przeprowadzonych przez Walerego Pisarka w 1991 r., wynikają następujące korelacje aksjologiczne pojęć społeczno-politycznych:

\begin{tabular}{|l|l|}
\hline \multicolumn{1}{|c|}{ Pozytywne } & \multicolumn{1}{c|}{ Negatywne } \\
\hline uczciwość 73\% & dyktatura 49\% \\
miłość 66\% & anarchia 47\% \\
sprawiedliwość 65\% & inflacja 36\% \\
zgoda 60\% & nietolerancja 34\% \\
wolność 59\% & nomenklatura 34\% \\
\hline
\end{tabular}

W badaniach socjolingwistycznych uwzględnia się kategorie kulturowe większego formatu, a mianowicie kulturowe parametry grup społecznych: genderowych, wiekowych, klasowych, zawodowych, regionalnych i in. Zakłada 
się, że w sposób zasadniczy warunkują one procesy kodowania i dekodowania informacji językowej. Badanie socjolektów od strony charakterystycznej dla każdej grupy społecznej konceptualizacji świata stanowi perspektywiczny kierunek współczesnej lingwistyki kulturowej.

\subsubsection{Kontekst sytuacyjny}

Można wyodrębnić cztery najważniejsze aspekty oddziaływania kontekstu sytuacyjnego na funkcjonowanie jednostek języka:

- kontekst sytuacyjny a znaki naturalne;

- funkcja kompensacyjna sytuacji komunikacyjnej;

- kontekst sytuacyjny a znaki deiktyczne.

Kontekst sytuacyjny a znaki naturalne. W lingwistyce komunikacyjnej zakłada się zróżnicowany charakter narzędzi przekazywania informacji. Tak więc Gregory Bateson (1985: 150 i n.) zaproponował dychotomię znaków analogowych i cyfrowych. Znaki cyfrowe (tzn. symboliczne, konwencjonalne) funkcjonują według zasady 'tak' (+) lub 'nie' (-), tzn. są przyporządkowane zachowywanym $\mathrm{w}$ pamięci kategoriom pojęciowym. Obecność desygnatu w sytuacji stosowania (artykułowania) takiego znaku nie jest konieczna, ponieważ zakres jego znaczenia jest zakodowany w systemie intelektualnym człowieka. Znaki analogowe zmieniają się w sposób ciagłły w ślad za wielkościami w zdarzeniu referencyjnym; są to znaki naturalne, pochodzące $\mathrm{z}$ kontekstu komunikacji, zrozumiałe same w sobie. Ich interpretacja w dużym stopniu zależy od sytuacji komunikacyjnej, tzn. od naturalnych, oczywistych powiązań zdarzeń i stanów rzeczy. Znaki analogowe, takie jak miejsce, czas komunikacji, środki przekazu, otoczenie fizyczne itd. (zob. Kravčenko 2001: 90), należą do ewolucyjnie pierwotnych, są ponadto stosowane w komunikacji człowieka i w komunikacji zwierząt (a także w tzw. komunikacji międzygatunkowej). Jak ważne ze względu na charakter i treść oddziaływania werbalnego jest miejsce komunikacji, mówi następujący fragment prasowy o lokalizacji reklam zewnętrznych firm pogrzebowych:

Reklama również wymaga subtelności i wrażliwości. Banner umieszczony w okolicy szpitala może tylko przynieść efekt przeciwny. Antyreklamą będzie też napis na tramwaju lub autobusie: 'Zapraszamy do nowej firmy pogrzebowej'. Pasażerowie nie mogą się czuć, jakby rano do pracy jechali karawanem (Rzeczpospolita 5 XI 2004).

Funkcja kompensacyjna sytuacji komunikacyjnej. Kontekst sytuacyjny, określany w literaturze lingwistycznej także jako k o n s y t u acja, przyczynia się do nasilenia procesów kompresji strukturalnej wyrażeń 
językowych, tzn. usuwania elementów, uważanych za informacyjnie zbędne, powtarzające informację, płynącą $\mathrm{z}$ samego otoczenia aktu mowy. Badacze mowy potocznej w szczególności piszą o wysokim stopniu jej analityzmu, tzn. unikania morfologicznych wykładników związków składniowych (Zemskaja i in. 1981: 29; Warchala 2003: 107), z tym że uwarunkowane konsytuacją wyzerowanie pozycji składniowych może dotyczyć także członów konstytucyjnych zdania: podmiotu, orzeczenia itd., por. przykład z książki Warchali:

$-\mathrm{I}$ ?

- Do przodu.

Kontekst sytuacyjny a znaki deiktyczne. Konsytuacja jest podstawą funkcjonowania znaków deiktycznych, o których Warchala (2003: 91) pisze: ,[ich] Interpretacja zdąża od strony sytuacji zewnętrznej i tylko odniesienie do sytuacji rozstrzyga o znaczeniu wyrażenia". Kod deiktyczny stanowi jeden z podsystemów kodowania informacji w języku (Kiklewicz 2007b: 328), funkcjonuje w obszarze komunikacji interpersonalnej, w warunkach kontaktu fizycznego (zintegrowania) partnerów, gdy sytuacja referencyjna jest tożsama z sytuacją komunikacyjną. Deiktyczna konceptualizacja obiektów ma charakter indekowy, tj. bezpośrednio oparta jest na percepcji desygnatu przez podmiot komunikacyjny: ,zaimek [deiktyczny - A. K.] staje się tu indeksem odsyłającym, [...] mówiącym nam, która część świata jest denotatem grupy imiennej” (Warchala 2003: 91 i n.).

Niektórzy badacze traktują kontekst jako sytuację referencyjną (zob. Przybyszewski 2010). Takie pojmowanie kontekstu zaproponował w słynnym artykule „Lingwistyka a poetyka” z 1960 roku Roman Jakobson (1989), który pisał, że kontekst musi być postrzegany przez adresata lub być werbalnym (przynajmniej zakładać możliwość werbalizacji). Sytuacja referencyjna jednak niekoniecznie wchodzi do obszaru percepcji podmiotów językowych - przecież mówimy i piszemy o stanach rzeczy, które nie zawsze doświadczamy za pomocą zmysłów, a które często są wyimaginowane. Stosowanie do takich zjawisk pojęcia kontekstu należałoby uważać za nieuzasadnione.

\subsubsection{Kontekst społeczny}

Na kontekst społeczny składają się relacje międzyludzkie, opisywane w takich dychotomicznych kategoriach jak: intymność - formalność, rywalizacja współpraca, równość - nierówność, zaangażowanie - obojętność i in. (zob. Nęcki 2000: 94). Kontekst społeczny zachowań językowych jest opisywany w różnych ujęciach, z nich najważniejsze są dwa: socjo- oraz pragmalingwistyczne. 
W socjolingwistyce dokonuje się opisu rozmaitych form odmienności systemu języka w zależności od dwóch parametrów: (1) właściwości habitualnych (czy też statusowych) podmiotów językowych: biologicznych, etnicznych, demograficznych i in.; (2) właściwości funkcjonalnych sytuacji komunikacyjnych, dotyczących typów zachowań językowych oraz typów kontekstów interakcyjnych. W najnowszej koncepcji odmian społecznych języka (zob. Kiklewicz 2009a, c; 2010a) w sposób aksjomatyczny zostało wyodrębnionych dziewięć typów wariantów języka, które stanowią różne konfiguracje ich właściwości habitualnych i funkcjonalnych.

Pragmalingwistyczne ujęcie kontekstu społecznego dotyczy jego wpływu na realizację interakcji za pośrednictwem języka naturalnego. W te ori i a któ w mowy zakłada się, że właściwe odczytanie zachowań językowych wymaga uwzględnienia nie tylko językowej formy i struktury komunikatu, lecz także

[...] kontekstu wypowiedzi, tj. jej usytuowania (czas i miejsce), ról społecznych pełnionych przez interlokutorów, hierarchii zawodowej czy rodzinnej między nimi, jak również emocjonalności, intencjonalności wypowiedzi (Komorowska 2008: 54).

W te orii dyskursu przyjmuje się perspektywę badawczą: od scenariusza interakcji do środków znakowych. W tym przypadku punktem odniesienia nie jest indywidualny zamiar nadawcy komunikatu (oraz towarzyszące mu stany mentalne i emocjonalne), lecz zespołowa praktyka komunikacyjna, a także obowiązujące w niej normy zachowań. A więc zadanie badawcze polega tu na tym, aby poprzez analizę treści komunikatów znakowych (tekstów) dokonać społeczno-historycznej i ideologicznej rekonstrukcji „ducha czasu” (Černjavskaja 2003: 70).

Kontekst ideologiczny jest uwzględniany także w stylistyce funkc j on a ln ej, która m.in. opisuje zmiany językowe, uwarunkowane zmianami w sferze społeczno-politycznej. Tak więc demokratyzacja życia politycznego powoduje innowacje $\mathrm{w}$ zakresie sytuacji, sfer oraz obszarów komunikacyjnych, staje się przyczyną nie tylko nasilenia neologizmów, lecz także ruchomości stylistycznej tekstów literatury artystycznej, reklamy, mediów masowych, a nawet tekstów naukowych.

\subsubsection{Kontekst dyspozycyjno-intencjonalny}

W punkcie 3.2 kontekst dyspozycyjno-intencjonalny został zdefiniowany jako stany i zamierzenia partnerów komunikacyjnych. Jest to szczególnie ważny aspekt współczesnego opisu języka, który ogólnie można określić jako a n tro - 
p olog i z m. Tak więc rosyjska badaczka Tamara G. Vinokur (1993: 56) pisze o nasileniu we współczesnym językoznawstwie podmiotowego ujęcia języka, tzn. takiej jego interpretacji, która uwzględnia nie tyle, dlaczego ani jak zostało coś powiedziane, ile kto powiedział. Jakkolwiek strukturaliści - według aforystycznego określenia Jurija N. Karaulova - zakładali: „Za każdym tekstem stoi system języka", to u podstaw współczesnych badań lingwistycznych, szczególnie antropolingwistycznych, leży teza: „Za każdym tekstem stoi osoba mówiąca".

We współczesnym językoznawstwie można przede wszystkim wyodrębnić dwa kierunki badań, skupiające uwagę na tym aspekcie zewnętrznego uwarunkowania działalności językowej: (1) teorię aktów mowy oraz (2) semantykę modalną i intensjonalną.

Podstawową kategorią aktów mowy jest in te n cj a nadawcy komunikatu. Zakłada się, że akt mowy jest działaniem, tzn. realizacją zamiaru podmiotu językowego, najczęściej względem adresata. Stąd ogólna eksplikacja takich aktów mowy: ' $X$ mówi $S$ do $Y$-a; mówiąc, $X$ chce, żeby zaszło zdarzenie $R$ z udziałem lub za pośrednictwem $Y$-a; $X$ jest przekonany, że w ten sposób spowoduje zdarzenie $R$ z udziałem lub za pośrednictwem $Y$-a' (zob. Kiklewicz 2007b: 102). Mimo że badacze komunikacji językowej są świadomi faktu, że zaprogramowany przez nadawcę zamiar działania językowego nie zawsze przekłada się na adekwatne efekty, to jednak u podstaw większości klasyfikacji aktów mowy leży właśnie pojęcie intencji. Przegląd tych klasyfikacji zaprezentowałem w pracy Tęcza nad potokiem... (Kiklewicz 2010c: 74 i n.).

W semantyce modalnej i intensjonalnej przyjmuje się tezę, że znaczenie prawdziwościowe wyrażenia językowego nie polega na jego odniesieniu referencyjnym, lecz na jego zgodności z nastawieniem sądzeniowym (czy też propozycjonalnym) podmiotu. Takie wyrażenie jak:

\footnotetext{
X wierzy, że...

$\mathrm{X}$ ma nadzieję, że...

X pamięta, że...

X uważa, że...
}

wskazują na fenomenologiczne ukierunkowanie umysłu, innymi słowy zakładają istnienie zespołu intensjonalnych możliwych światów, czyli tego, w co wierzy $X$, na co ma nadzieję, co pamięta, co uważa itd. W językach naturalnych, które Jaakko Hintikka (1992: 37 i n.) - autor teorii możliwych światów, określa jako języki drugiego rzędu, wyrażenie językowe posiada znaczenie prawdziwości pod warunkiem, że odnosi co najmniej do jednego możliwego świata w systemie konceptualnym nadawcy. Znaczenie nominatyw- 
ne zdania $w$ języku drugiego rzędu zależy nie tyle od znaczeń nominatywnych jego terminów, co od tego, czy odpowiada ono nastawieniom propozycjonalnym. Warto porównać dwa wyrażenia:

Francuzi są najmniej wysportowanym narodem w Europie.

Jan uważa, że Francuzi są najmniej wysportowanym narodem w Europie.

Jakkolwiek pierwsze wyrażenie zweryfikujemy na podstawie jego treści asercyjnej, wynikającej ze znaczeń leksykalnych syntaktemów oraz struktury gramatycznej zdania (i w tym właśnie przypadku możemy mieć wątpliwości co do prawdziwości tego stwierdzenia), to weryfikacja drugiego wyrażenia będzie dotyczyła przede wszystkim sądu modalnego: 'Jan uważa...', a mianowicie tego, czy treść asercyjna zdania zależnego koresponduje przynajmniej z jednym możliwym światem w zakresie tego, co uważa Jan.

Kontekst intensjonalny jest szczególnie intensywnie badany w obrębie składni funkcjonalnej; np. w wersji tej teorii, którą zaproponowałem w pracy Podstawy sktadni funkcjonalnej (Kiklewicz 2004b: 168 i n.), kontekst intensjonalny jest opisywany w terminologii modalności deontycznej.

\section{Zakończenie}

Zgodnie z podstawowym założeniem niniejszego tekstu historię językoznawstwa można podzielić na poszczególne okresy, w których dominuje określony pogląd na język, znajdujący wyraz w tym, że większość badaczy skupia uwagę na wyodrębnionym aspekcie znaków. Takie stanowisko metodologiczne pozwala na wyróżnienie sześciu paradygmatów językoznawstwa: (1) formalistycznego (tradycyjnego); (2) semazjologicznego (intensjonalnego); (3) onomazjologicznego (ekstensjonalnego); (4) strukturalnego; (5) poststrukturalnego (antropologicznego) oraz możliwego w przyszłości paradygmatu - (6) uniwersalistycznego (holistycznego). Ogólna tendencja dynamiki paradygmatów (w każdym razie w przekroju wieków XIX-XXI) polega na stopniowym un i k a n i u ję z y ka; jakkolwiek paradygmaty semazjologiczny i onomazjologiczny bazowały na znakach symbolicznych (konwencjonalnych), paradygmat strukturalny - na znakach ikonicznych (strukturalnie kompozycyjnych), to paradygmat antropologiczny uwzględnia przede wszystkim znaki symptomatyczne, bezpośrednio związane ze społecznym, kulturowym, geofizycznym, biologicznym itd. środowiskiem człowieka. Znaki symboliczne i ikoniczne w tym współcześnie panującym paradygmacie także są interpretowane pod względem powiązań z kontekstem motywacyjnym. 


\section{Bibliografia}

Apresjan, J. D. [Апресян, Ю. Д.] 1974. Лексическая семантика. Синонимические средства языка, Москва: Наука.

Awdiejew, A. 1999. „Standardy semantyczne w gramatyce komunikacyjnej (teoria i zastosowanie)", [w:] A. Awdiejew (red.), 33-68.

Awdiejew, A. (red.), 1999. Gramatyka komunikacyjna, Warszawa-Kraków: PWN.

Bachtin, M. M. 1979. Эстетика словесного творчества, Москва: Искусство.

Barchudarov, L. S. [Бархударов, Л. С.] 1975. Язык и перевод, Москва: Международные отношения.

Bateson, G. 1985. Mind and Nature. A Necessary Unity, Fontana: Hampton Press.

Bevir, M. 1999. The Logic and the History of Ideas, Cambridge: Cambridge University Press.

Birken-Silverman, G. 2005. „Code-Switching in der Kommunikation italienischer Migrantenjugendlichen: Frot-zelaktivitaten", [w:] W. Hinnenkamp, K. Meng (red.), $105-144$.

Bobrowski, I. 1998. Zaproszenie do językoznawstwa, Kraków: Wydawnictwo Instytutu Języka Polskiego PAN.

Bodeker, Н. Е. [Бодекер, Х. Э.] (red.), 2010. История понятий, история дискурса, история метафор, Москва: Новое Литературное Обозрение.

Boguslavskij, I. М. [Богуславский, И. М.] 1996. Сфера действия лексических единиц, Москва: Языки русской культуры.

Braunmüller, K. 1985. „Überlegungen zu einer Theorie der sog. Nebenwortarten”, Zeitschrift für germanistische Linguistik 13, 295-309.

Christmann, H. H., Baum, R. 1994. Geschichte der Sprachwissenschaft und der neueren Philologien, Tübingen: Narr.

Coşeriu, E. 2004. Der Physei-Thesei-Streit. Sechs Beiträge zur Geschichte der Sprachphilosophie, Tübingen: Narr.

Černjavskaja, V. Е. [Чернявская, В. Е.] 2003. „От анализа текста к анализу дискурса: немецкая школа дискурсивного анализа", Филологические науки 3, 68-76.

Drosdowski, G. (red.), 1984. Duden. Grammatik der deutschen Gegenwartssprache, Mannheim-Wien-Zürich: Dudenverlag.

Gajda, S. 2010. „Intertekstualność a współczesna lingwistyka”, [w:] J. Mazur, A. Małyska, K. Sobstyl (red.), 13-23.

Glück, H. (red.), 1993. Metzler Lexikon Sprache. Stuttgart-Weimar: J. B. Metzler.

Grochowski, M. 1997. Wyrażenia funkcyjne. Studium leksykograficzne, Kraków: Wydawnictwo Instytutu Języka Polskiego PAN.

Grzegorczykowa, R. 1992. „Problemy dyskusyjne w opisie zjawiska referencji”, Etudes de linguistique Romane et Slave, 271-281.

Hall, E. 1959. The Silent Language, Garden City-New York: Anchor Press [ttum.: Hall, E. 1987. Bezgłośny język, Warszawa: Państwowy Instytut Wydawniczy].

Harris, R. 1981. The Language Myth, London: Duckworth. 
Helbig, G., Buscha, J. 1993. Deutsche Grammatik. Ein Handbuch für den Ausländerunterricht, Leipzig: Langenscheidt.

Hinnenkamp, W., Meng, K. 2005. „Einleitung”, [w:] W. Hinnenkamp, K. Meng (red.), $7-16$.

Hinnenkamp, W., Meng, K. (red.), 2005. Sprachgrenzen überspringen. Sprachliche Hybridität und polykulturelles Selbstverständnis, Tübingen: Narr.

Hintikka, J. 1992. Eseje logiko-filozoficzne, Warszawa: PWN.

Ibragimova, V. L. [Ибрагимова, В. Л.] (red.), 2009. Система языка: синхрония и диахрония, Уфа.

Jakobson, R. 1989. W poszukiwaniu istoty języka. Wybór pism 2, Warszawa: PIW.

Karolak, S. 2002. Podstawowe struktury składniowe języka polskiego, Warszawa: Instytut Slawistyki PAN.

Kasperski, E. (red.), 2000. Rozważania metodologiczne. Język - literatura - teatr, Warszawa: UW.

Kempgen, S. 1981. 'Wortarten' als klassifikatorisches Problem der deskriptiven Grammatik. Historische und systematorische Untersuchungen am Beispiel des Russischen, München: Sagner.

Kiklewicz, А. [Киклевич, А.] 1998. Язык и логика. Лингвистические проблемь квантификации, München: Sagner.

Kiklewicz, А. [Киклевич, А.] 1999. Лекиии по функциональной лингвистике, Минск: БГУ.

Kiklewicz, A. 2004. Podstawy składni funkcjonalnej, Olsztyn: Wydawnictwo UWM.

Kiklewicz, A. 2005. „Zur suggestiven Funktion des Textes”, Acta Neophilologica 7, 131-146.

Kiklewicz, A. 2006. „Dyfuzja semantyczna w języku i tekście (II)”, LingVaria 1 (2), 9-20.

Kiklewicz, A. 2007a. Aspekty teorii względności lingwistycznej, Olsztyn: Wydawnictwo UWM.

Kiklewicz, A. 2007b. Zrozumieć język. Szkice z filozofii języka, semantyki, lingwistyki komunikacyjnej, Łask: Leksem.

Kiklewicz, A. 2009a. „Dystrybucyjny model odmian społecznych języka”, Stylistyka 18, 33-54.

Kiklewicz, А. [Киклевич, А.] 2009b. „Слово и образ. О роли визуализации в теоретической лингвистике", [w:] В. Л. Ибрагимова (red.), 87-95.

Kiklewicz, A. 2009c. „Warianty języka: próba systematyzacji”, Biuletyn Polskiego Towarzystwa Językoznawczego 65, 67-86.

Kiklewicz, A. 2010a. „A distributional model of language variants”, Studies in Polish Linguistics 5, 7-26.

Kiklewicz, A. 2010b. „Metafora jako intertekst. Elementy teorii przekodowania pragmatycznego", [w:] J. Mazur, A. Małyska, K. Sobstyl (red.), 239-250.

Kiklewicz, A. 2010c. Tęcza nad potokiem... Kategorie lingwistyki komunikacyjnej, socjolingwistyki i hermeneutyki lingwistycznej w ujęciu systematycznym, Łask: Leksem. 
Kiklewicz, А. [Киклевич, А.] (red.), 1999. Паланістыка - Полонистика - Polonistyka 1999, Мінск: Права і эканоміка.

Kiklewicz, A. (red.), 2004. Paradygmaty filozofii języka, literatury $i$ teorii tekstu, Słupsk: Wydawnictwo PAP.

Kintsch, W., Dijk, T. A. van. 1978. „Toward a model of text comprehension and production", Psychological Review 85, 363-394.

Komorowska, E. 2008. Pragmatyka dyrektywnych aktów mowy, Szczecin-Rostock: Print Group.

Kravčenko, A. V. [Кравченко, А. В.] 2001. Знак, значение, знание, Иркутск: ОГУП.

Leszczak, O. [Лещак, O.] 2000. „К проблеме понятия функции в функционально-прагматической методологии", [w:] Е. Kasperski (red.), 243-254.

Lewicki, A. M. 1996. „Styl oficjalny i styl potoczny w reklamie”, [w:] J. Miodek (red.), 111-120.

Lotman, J. М. [Лотман, Ю. М.] 1973. „Знаковый механизм культуры”, [w:] J. М. Lotman (red.), 196-206.

Lotman, J. М. [Лотман, Ю. М.] (red.), 1973. Сборник статей по вторичнымм моделирующим системам, Тарту: Издательство Тартуского университета.

Lyons, J. 1975. Wstęp do językoznawstwa, Warszawa: PWN.

Mazur, J. Małyska, A., Sobstel, K. (red.), 2010. Intertekstualność we wspótczesnej komunikacji językowej, Lublin: Wydawnictwo UMCS.

McLuhan, M. 2001. Wybór tekstów, Warszawa: Wydawnictwa Naukowo-Techniczne.

McLuhan, M. 2004. Zrozumieć media, Warszawa: Zysk i S-ka.

McQuail, D. 2008. Teoria komunikowania masowego, Warszawa: PWN.

Mikus, R.-F. 1972. Principes de syntagmatique, Paris: Didier.

Miodek, J. (red.), 1996. O zagrożeniach i bogactwie polszczyzny, Wrocław: Towarzystwo Przyjaciół Polonistyki Wrocławskiej.

Nęcki, Z. 2000. Komunikacja międzyludzka, Kraków: Antykwa.

Nycz, R. 1993. Tekstowy świat. Poststrukturalizm a wiedza o literaturze, Warszawa: Universitas.

Ogden, C. K., Richards, I. A. 1969. The Meaning of Meaning. A Study of the Influence of Language upon Thought and of the Science of Symbolism, London: Routledge, Kegan Paul.

Ozóg, K. 2001. Polszczyzna przełomu XX i XXI wieku. Wybrane zagadnienia, Rzeszów: Otwarty Rozdział.

Phillipson, N., Skinner, Q. (red.) 1993. Political Discourse in Early Modern Britain, Cambridge: Cambridge University Press.

Piernikarski, C. 1990. Struktura syntaktycznych grup homogenicznych (w zestawieniu z niektórymi typami grup heterogenicznych), Wrocław: Ossolineum.

Pisarek, W. 2000. „Polskie słowa sztandarowe i ich publiczność: lata dziewięćdziesiąte”, Zeszyty Prasoznawcze 3-4, 19-41.

Pisarek, W. 2002. Polskie stowa sztandarowe i ich publiczność, Kraków: Universitas.

Pisarkowa, K. 2000. Językoznawstwo Bronisława Malinowskiego. T. 1. Więzy wspólnego języka, Kraków: Universitas. 
Pociechina, Н. [Потехина, E.] 2010. Грамматическая вариативность в славянских языках: морфонологический аспект, Olsztyn: Wydawnictwo UWM.

Pocock, J. G. A. 1972. Politics, Language and Time, London: Methuen.

Polański, R. (red.), 1999. Encyklopedia językoznawstwa ogólnego, Wrocław: Ossolineum.

Prokopczuk, K., Tiutenko, A. 2004. „Textpareadigma und Hypertext”, [w:] A. Kiklewicz (red.), 231-240.

Przybyszewski, S. 2010. Kontekst a wspólna płaszczyzna w komunikacji (w druku).

Quine, W. V. O. 1995. Różności. Stownik prawie filozoficzny, Warszawa: Aletheia.

Reformatskij, A. А. [Реформатский, A. A.] 1987. Лингвистика и поэтика, Москва: Наука.

Rewers, E. 1996. Język i przestrzeń w poststrukturalistycznej filozofii kultury, Poznań: Wydawnictwo UAM.

Rudenko, D. I. 1993, „Лингвофилософские парадигмы: границы языка и границы культуры”, [w:], J. S. Stepanov (red.), 101-173.

Saloni, Z. 1999a. „Kontekst językowy”, [w:] R. Polański (red.), 313-314.

Saloni, Z. 1999b. „Semantyka”, [w:] R. Polański (red.), 521-523.

Saussure, F. de. 2002. Kurs językoznawstwa ogólnego, Warszawa: PWN.

Schuchardt, H. 1912. „Sachen und Wörter”, Anthropos 7, 827-839.

Skalski, T. 2002. Sprawcza funkcja języka. Z zagadnień naturalizacji umysłu i języka, Łódź: Wydawnictwo UŁ.

Spivey-Knowlton, M. J., Trueswell, J. C., Tanenhaus, M. K. 1993. „Context effects in syntactic ambiguity resolution: Discourse and semantic influences in parsing reduced relative clauses", Canadian Journal of Experimental Psychology 47, 276-300.

Stepanov, J. S. [Степанов, Ю. С.] 1985. В трехмерном пространстве языка. Семиотические проблемы лингвистики, философии, искусства, Москва: Наука.

Stepanov, J. S. [Степанов, Ю. С.] (red.), 1980. Гипотеза в современной лингвистике, Москва: Наука

Stepanov, J. S. [Степанов, Ю. С.] (red.), 1993. Философия языка: в границах и вне грании, Харьков: Око.

Szumska, D. 1999. „Niebezpieczne związki, czyli meandry adiektywizacji”, [w:] A. Kiklewicz (red.), 4-28.

Świątek, J. 1998. W świecie powszechnej metafory. Metafora językowa, Kraków: Wydawnictwo Oddziału PAN.

Šajkevič, А. J. 1980. „Гипотезы о естественных классах и возможность количественной таксономии в лингвистике”, [w:] J. S. Stepanov (red.), 319-357.

Šeljakin, M. А. [Шелякин, М. А.] 2002. Язык и человек, Тарту: Издательство Тартуского университета.

Taranovskij, K. F. [Тарановский, К. Ф.] 1967. „Пчелы и осы в поэзии Мандельштама: к вопросу о влиянии Вячеслава Иванова на Мандельштама”, [w:] To Honor Roman Jakobson: Essays on the Occasion of His Seventieth Birthday 3, The Hague: Mouton, 1973-1995. 
Topolińska Z. (red.) 1984, Gramatyka wspótczesnego języka polskiego. Składnia, Warszawa: PWN.

Trubiecki, N. S. 1970. Podstawy fonologii, Warszawa: PWN.

Tynjanov, J. S. [Тынянов, Ю. С.] 2004. Проблемы поэтического языка, Москва: Наука.

Vinokur, T. G. [Винокур, Т. Г.] 1993. Говорящий и слушающций. Варианты речевого общения, Москва: Норма.

Vizel', М. [Визель, М.] 1999. „Гипертексты по ту и эту стороны экрана”, Иностранная литература 10, 170-177.

Volośinov, V. N. [Волошинов, В. Н.] 1995. Философия и социология гуманитарных наук, Санкт-Петербург: Аста-Пресс Ltd.

Warchala, J. 2003. Kategoria potoczności w języku, Katowice: Wydawnictwo UŚ.

Ważnik, S. [Важнік, C.] 2008. Кантрастыўны сінтаксіс польскай $і$ беларускай моў. Семантыка і дыстрыбуцьыя дзеяслоўнага прэдыката, Мінск: Права і эканоміка.

Weydt, H., Ehlers, K.-H. 1987. Partikel-Bibliographie: internationale Sprachenforschung zu Partikeln u. Interjektionen, Frankfurt am Main etc.: Peter Lang Verlag.

Wittgenstein, L. 1969. Schriften 1. Tractatus logico-philosophicus. Tagebücher 1914-1916. Philosophische Untersuchungen, Frankfurt am Main: Suhrkamp.

Zemskaja, E. A., Kitajgorodskaja, M. V., Širjaev E. N. [Земская, Е. А., Китайгородскаая, М. В., Ширяев, Е. Н.] 1981. Русская разговорная речь. Общие вопросы. Словообразование. Синтаксис, Москва: Наука.

Zill, R. 2010. „'Субструктуры мышления’. Границы и перспективы истории метафор по Хансу Блюменбергу”, [w:] Н. E. Bodeker (red.), 155-188.

Zmarzer, W. 1994. „О явлении 'семантического плюрализма' в современном русском языке”, Przeglad Rusycystyczny 3-4, 219-224.

Zvegincev, V. А. [Звегинцев, В. А.] 1968. Теоретическая и прикладная лингвистика, Москва: Просвещение.

Zvegincev, V. А. [Звегинцев, В. А.] 1976. Предложение и его отночение к языку и речи, Москва: Издательство МГУ.

Żmigrodki, P. 1995. Zdania metaforyczne $w$ języku polskim, Katowice: Wydawnictwo UŚ. 